\title{
Geographies of aging
}

In recent decades human geographers based in North America and Europe from both positivist and critical traditions have contributed to debates on geographies of aging. Geographical work with an empirical positivist approach has focused on understanding spatial patterns of residence and service provision as well as migration from a life cycle perspective (such as Plane 1999; Rogerson and Kim 2005). Others have been inspired by feminist and post modern theory in conceptualizing aging and space (such as Katz and Monk 1993; Harper and Laws 1995; Pain 1997). In 1995 Harper and Laws identified the aging body as pivotal to the social construction of later life and to the peripheralization of older people into discrete locations (such as retirement communities and sheltered housing).

Space provides an important dimension in the identification of oneself or others as old. Glenda Laws (1994) has examined the impact of domestic segregation on identities in old age in sheltered housing and retirement communities, settlements which have a minimum age of 50 (see also McHugh 2003). The home is also seen as an appropriate place for older people, with an expectation that as we age we spend more time there, with 'disengagement' /withdrawal from other spaces (Pain 2001, 158). This perspective has been criticised as it fails to criticize the historical and cultural specificity of disengagement (ibid). Droogleever Fortuijn et al (2006) challenge this view of spatial disengagement and the idea of older adults as inactive and 
unproductive agents and stress the productive, non paid contribution of older adults to local economies.

Rachel Pain (1997) has contributed to debates on the spatialities of fear for older people, as well as the role of discourses of class, ability, and gender in the spatial construction and experience of old age via the use of leisure spaces (Pain et al. 2000). In Full Circles (Katz and Monk 1993) a number of writers trace how space and place construct experience of changes over the life course, and how social class, ethnicity, community, and family, as well as personal experiences and attitudes, play a role in understanding differences in women's experiences of age. Katz and Monk (ibid) highlight the idea of a changing lifecourse rather than a fixed life cycle. Whereas the term life cycle is imbued with implications of predictable changes, 'multiple turns', and links life experiences with a 'relatively fixed or inevitable series of biological stages and ages', 'life course' is more open to the multiplicity of paths that individuals and households make take through life (ibid). Rather than employing old age as a chronological descriptor, socially and economically constructed aspects of old age, feminist and postmodern geographers have emphasised the importance of space in constructions of aging (see above).

In this focus issue we seek to add incrementally to geographical knowledge by offering multiple ways of knowing aging. The first two papers (David A. Plane and Jason R. Jurjevich and Kevin McHugh and Ann Fletchall) draw on different epistemological traditions within human geography, and illustrate how when linked together a quantitative analysis of population redistribution 
and migration flows by age in the USA provides a useful context to a microsociological case study of one retirement community, which draws on the lived experience of residents. The migration of older adults is often to destinations with special climatic and other natural amenities, sometimes the result of a search of a place residence in an age-defined retirement community (for people above the age of 50 years). According the Glenda Laws (1995) these unreal places existing outside time and social change are long established, the oldest one Youngtown was established in the 1950s in Arizona. We secondly seek to contribute to ways of looking at activity and aging. The aging body is equated in capitalist societies with a lack of value primarily because it is no longer productive (Bourdieu 1984; Mowl et al 2000). Older people are typically characterized as recipients of care who make ever increasing demands on over stretched and under funded social care services. In the third paper Irene Hardill and Sue Baines highlight the contribution of older people as active citizens and givers of care to non household members through undertaking unpaid voluntary work helping members in their white working class community in England. Unpaid voluntary work can give a role and sense of worth and identity for those 'beyond the labor market' because of age. This paper illustrates how people may actively create and resist particular age identities through their use of space and place.

There is a growing body of evidence on demography and aging in 'grey literature'. In the fourth paper Anne Green illustrates how grey literature can be critiqued and used within the academy. She presents a summary review of an Organization for Economic Co-operation and Development (OECD) 
report that has identified population aging as one of the most important challenges facing OECD countries. This review highlighted the need for people to undertake paid work longer and for job prospects for older workers to be enhanced. But while this recommendation may seem sensible from a policy perspective against an aging demographic profile, in the final paper Helen Lawton Smith looks at a case study a dynamic regional economy, Oxfordshire in England, where there are already very pronounced demographic profiles for some occupational groups skewed towards older adults.

In the first paper David A. Plane and Jason R. Jurjevich of the University of Arizona analyze special county-to-county migration tabulations of Census 2000 data using graphs, maps, and statistical measures to explore migration flows. They note that when flows are disaggregated by age, radically different patterns of net population redistribution are taking place upwards and downwards within the national urban hierarchy. As people age through the life course, however, they migrate for very different reasons, and their destination choices reflect radically different considerations and preferences. Migration they argue has major repercussions for the nature of family ties. The spatial separation of parents and their adult children should become increasingly important as the baby boomers age. And increasingly as life spans are extended, it is the location of those adult children at the empty-nester and early retirement stage of the life course, rather than during the midcareer/childrearing years, that is of critical concern for caring for the oldest elderly. Because the aging of populations is one of the few things in the 
social sciences that we can predict with some certainty, we conclude by speculating about what shifting age structure portends for future migration patterns.

The second paper Kevin McHugh and Ann Fletchall, of Arizona State University focus on Youngtown, Arizona, the first retirement community in the US. They tell the story of the life and death of Youngtown as a retirement haven, including the response of seniors to the loss in community identity: out-migration, anger, depression and eventual acceptance among older people who linger. Retirement enclaves offer what the authors term a freezeframe view of place what (Laws 1995) argues is an unreal place existing outside time and social change. Seniors migrate to Sunbelt retirement enclaves expecting stability: to enjoy active and rewarding lives for as long as possible amongst like-minded retiree brethren in an ordered, controlled and predictable environment (ibid). The events which unfolded in Youngtown upset long-held beliefs about community identity and stability. Insular, freezeframe dreams of community identity and stability common among seniors in retirement enclaves ultimately prove chimerical in the face of urban change. They end by looking at the 'death' of Youngtown as retiree haven, viewed in the sweep of shifting cultural attitudes about aging, and suggest it may be a harbinger, the opening notes in a requiem for de jure retirement communities.

Older people are typically characterized as recipients of care who make ever increasing demands on over stretched and under funded social care services. In the third paper Irene Hardill and Sue Baines highlight older people as active 
citizens and givers of care to non household members. They draw upon an in-depth study of volunteering in an English community beset by concentrated poverty and worklessness. Older adults, especially women, make up a significant component of those who gave time through volunteering for organisations that provide social welfare services for people in need in that community. While older adults had diverse ways of thinking about volunteering, it was often undertaken as an expression of care and support to others.

Anne Green presents a summary review of a strategically important Organization for Economic Co-operation and Development (OECD) report entitled 'Live Longer, Work Longer'. The report identifies population aging as one of the most important challenges facing OECD countries and highlights the need for people to undertake paid work longer and for job prospects for older workers to be enhanced. She uses the report as a platform to highlight differences between countries in demographic profiles and projections and in patterns of formal labor market participation amongst older workers, linking these to different welfare regimes and institutional contexts. Differences by gender and according to qualification level are highlighted also, so underlining the diversity of individual experiences. In particular the paper emphases the labour market challenges and opportunities that they pose. She ends by highlighting some strategic challenges that demographic change poses for economic and labour market policy at national and sub-national scales. 
The aging demographic profile of some occupational groups forms the context for the final paper by Helen Lawton Smith. She looks at technicians in the U.K. by drawing on an empirical study of the supply of technician training in engineering and science and technology sectors in Oxfordshire in South East England. The paper raises general issues about generational differences in perceptions of the nature of work and career paths, the importance of a 'bottom- up' policy response, and the link between cluster development and skills. In this case study, 'life course' with respect to career paths for both younger and older workers, is positioned within processes of technological and, in the public sector, institutional change and opportunities within the local economy. The consequences for individuals, employers and educators are profound, as 'employability' for individuals takes on new meanings, employers have to balance the retention of existing skills with the demands for new skills, and educators have to respond to the challenges of both.

\section{Literature Cited}

Bourdieu, P. 1986 Distinctions: a social critique of the judgement of taste. Cambridge, MA: Harvard University Press

Droogleever Fortuijn, J, M. van der Meer, V. Burholt, D. Ferring, S. Quattrini, I. Rahm Hallberg, G. Weber and C. Wenger. 2006. The activity patterns of older adults: a cross-sectional study in six European countries Population Space and Place 12(5): 353-369 
Harper, S. and G. Laws 1995. Rethinking the geography of ageing progress in Human Geography 19: 199-121

Laws, G. 1994. Aging, contested meanings, and the built environment. Environment and Planning A 26:1787-1802.

Katz, C. and J. Monk (eds) 1993. Full Circles London: Routledge

McHugh, K. 2003. Three faces of ageism: Society, image and place. Ageing \& Society 23:165-185.

Mowl, G, R. Pain, and C. Talbot 2000. The ageing body and the homespace Area 32(2): 189-97

Pain, R. 1997. 'Old age' and ageism in urban research: the case of fear of crime International Journal of Urban and Regional Research 21: 117-128

Pain, R., G. Mowl, and C. Talbot 2000. Difference and the negotiation of 'old age' Environment and Planning D 18: 377-393

Pain, R. 2001. age, generation and lifecourse in Pain, R, M. Barke, J. Gough, D. Fuller, R. MacFarlane and G. Mowl, 2001. Introducing Social Geographies Arnold: London 141-163

Plane, D.A. 1999. Demographic influences on migration. Regional Studies 27:375-383. 
Rogerson, P.A., and D. Kim. 2005. Population distribution and redistribution of the baby-boom cohort in the United States. Recent trends and implications. Proceedings of the National Academy of Sciences 102 (43): $15319-15324$.

IRENE HARDILL is Professor of Economic Geography at Nottingham Trent University, Nottingham NG1 4BU, U.K. E-mail: Irene.Hardill@ntu.ac.uk. Her research interests include the juggling of paid and unpaid work (unpaid caring activity as well as voluntary action), demography and aging and household decision making. 